\title{
A Reconstruction of the Caddo Salt Making Process at Drake's Salt Works
}

Paul N. Eubanks

Middle Tennessee State University

Follow this and additional works at: https://scholarworks.sfasu.edu/ita

Part of the American Material Culture Commons, Archaeological Anthropology Commons, Environmental Studies Commons, Other American Studies Commons, Other Arts and Humanities Commons, Other History of Art, Architecture, and Archaeology Commons, and the United States History Commons

Tell us how this article helped you.

This Article is brought to you for free and open access by the Center for Regional Heritage Research at SFA ScholarWorks. It has been accepted for inclusion in Index of Texas Archaeology: Open Access Gray Literature from the Lone Star State by an authorized editor of SFA ScholarWorks. For more information, please contact cdsscholarworks@sfasu.edu. 


\section{A Reconstruction of the Caddo Salt Making Process at Drake's Salt Works}

Creative Commons License

(c) (i) (8)

This work is licensed under a Creative Commons Attribution-NonCommercial 4.0 International License 


\title{
A Reconstruction of the Caddo Salt Making Process at DRAKE's SALT WORKS
}

\section{Paul N. Eubanks}

\begin{abstract}
The Caddo salt makers at the Drake's Salt Works Site Complex in northwestern Louisiana played a critical role in the production and trade of salt during the eighteenth century. Not only was salt used to season food, it would have also been important in the preparation of animal hides and the preservation of meat. Using archaeological data from recent excavations, as well as the historic record, this paper attempts to provide a reconstruction of the salt making process at Drake's Salt Works. This process involved filtering salt-impregnated soil using water from nearby streams and boiling the resulting liquid brine in a thin-walled, standardized bowl. The salt bowls appear to have been made on site using clay deposits found beneath the salt flats. Once the liquid brine had evaporated leaving behind the solid salt, the salt cakes were removed from the salt bowl and prepared for short-term storage or traded to the French, Spanish, or other American Indian groups without direct access to this commodity.
\end{abstract}

\section{Introduction}

From approximately A.D. 1650 until 1865, the Drake's Salt Works Site Complex in northwestern Louisiana was one of the south-central United States' most intensively-utilized salines. The salt produced at this site complex also played an important role in the eighteenth-century trading networks of the Caddo, French, Spanish, Koroa, Natchez, Quapaw, Tunica, and Wichita (Brain 1977, 1979, 1988, 1990; Brown 2004; Gregory 1973; Hofman 1984; Kidder 1998; McWilliams 1981; Swanton 1911, 1928, 1929, 1942, 1946; Webb and Gregory 1978; Wentowski 1970). Using recent archaeological data and historical documentation, this paper aims to provide a better understanding of the Caddo salt making process at Drake's Salt Works. In doing so, its ultimate goal is to offer a glimpse into the daily lives of the Caddo salt makers who worked at this saline.

Prior to the late seventeenth century, there was little motivation for the occupants of northwestern Louisiana to produce large quantities of salt (Eubanks 2014a). However, this was not the case following sustained European contact. While salt was frequently consumed by Europeans and American Indians simply for its taste, this mineral was often added to foods in order to fulfill a physiological requirement. If individuals did not meet this requirement, then their bodies would be unable to retain water and they would eventually die (Daupinée 1960; McCance 1936:823-830; Meneton et al. 2005; Morimoto 1993:389; Whitney et al. 1990). This would have been especially true among populations heavily reliant on plant-based foods low in sodium (e.g., maize) and in cases where salt served an important ritual function (Hunter 1940; Wentowski 1970). Although there is no evidence to suggest that salt was used prehistorically in the traditional Caddo homeland (Figure 1) or the Southeast more broadly to preserve meat, this was not the case following European contact. In addition, the use of salt in the preparation of animal hides also meant that the demand for this mineral would have increased dramatically during the early eighteenth century with the booming hide trade. With such a demand for salt, it may have been possible for the Caddo salt makers at Drake's Salt Works to profit both economically and politically from their participation in the production and exchange of this commodity. 


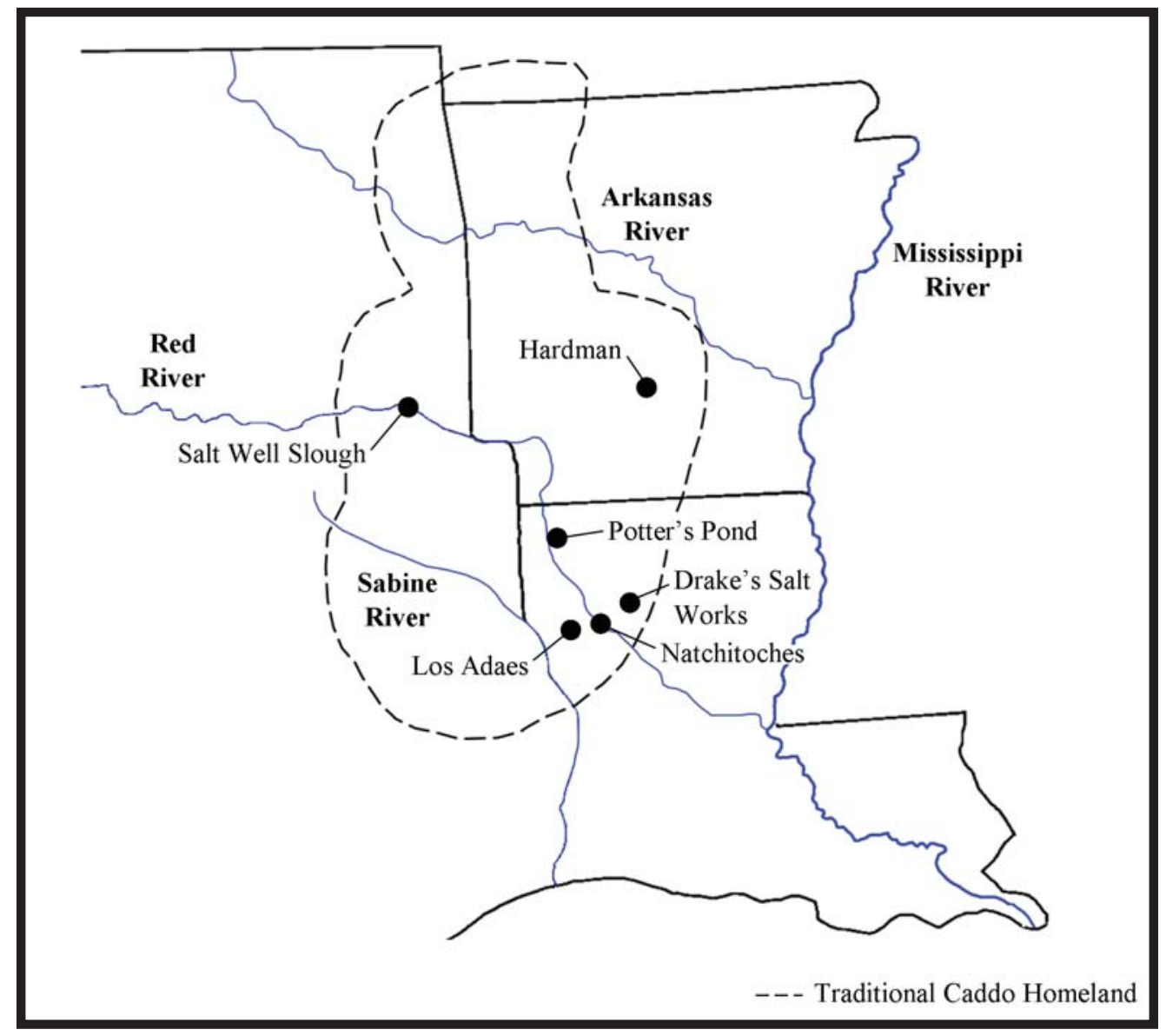

Figure 1. South-Central United States with the locations of sites mentioned in this article.

Drake's Salt Works sits atop a geological deposit known as a salt dome. The surface expression of the Drake's Salt Dome is approximately $1.5 \mathrm{~km}$ in diameter and contains several discrete "salt flats," or "licks" (Figure 2). The salt flats range in size from several dozen to several hundred meters in diameter and are composed primarily of salt-impregnated sand and clay. Two of these salt flats, the Upper (16WN30) and Little (16NA11) licks, are known to contain considerable evidence of eighteenth-century salt production (Eubanks 2014a).

In 2008, the United States Forest Service began a shovel testing program at the Upper Lick (16WN30) on a slight rise in the salt flat known as "Widdish Island" after the Caddo word for "salt" (Figure 3) (Eubanks and Smith 2012). Following this initial testing, the Upper Lick has hosted several Passport in Time projects ${ }^{1}$. In the fall of 2012, the Forest Service, in tandem with the Alabama Museum of Natural History's Gulf Coast Survey, surveyed six out of the seven salt licks at Drake's Salt Works. In addition to the Upper Lick, this survey revealed that the Little Lick (Figure 4) was also heavily involved in protohistoric/early historic-period salt production. At present, two $1 \times 6 \mathrm{~m}$ trenches and forty-four $1 \times 1 \mathrm{~m}$ test units have been excavated at the Upper Lick while at the Little Lick, three $1 \times 6 \mathrm{~m}$ trenches and two $1 \times 1 \mathrm{~m}$ test units have been excavated. Thus far, well over 15,000 salt bowl sherds have been recovered from these excavations. 

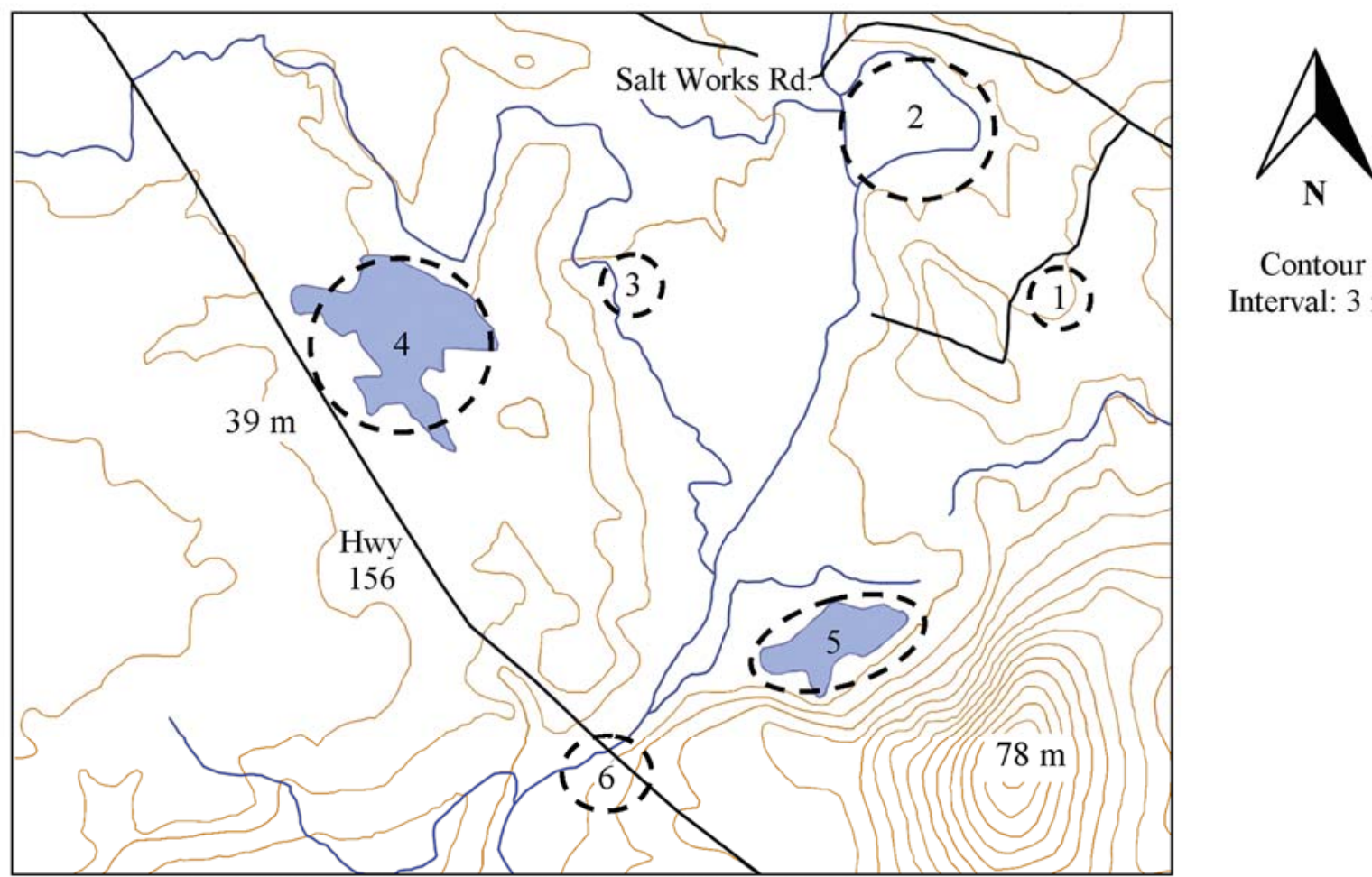

Contour

Interval: $3 \mathrm{~m}$

1- Jack's Lick, 2- Upper Lick, 3- Little Lick,

4-Big Lick, 5- Lower Lick, 6- Smith's Lick

Figure 2. Topographic map of Drake's Salt Works.

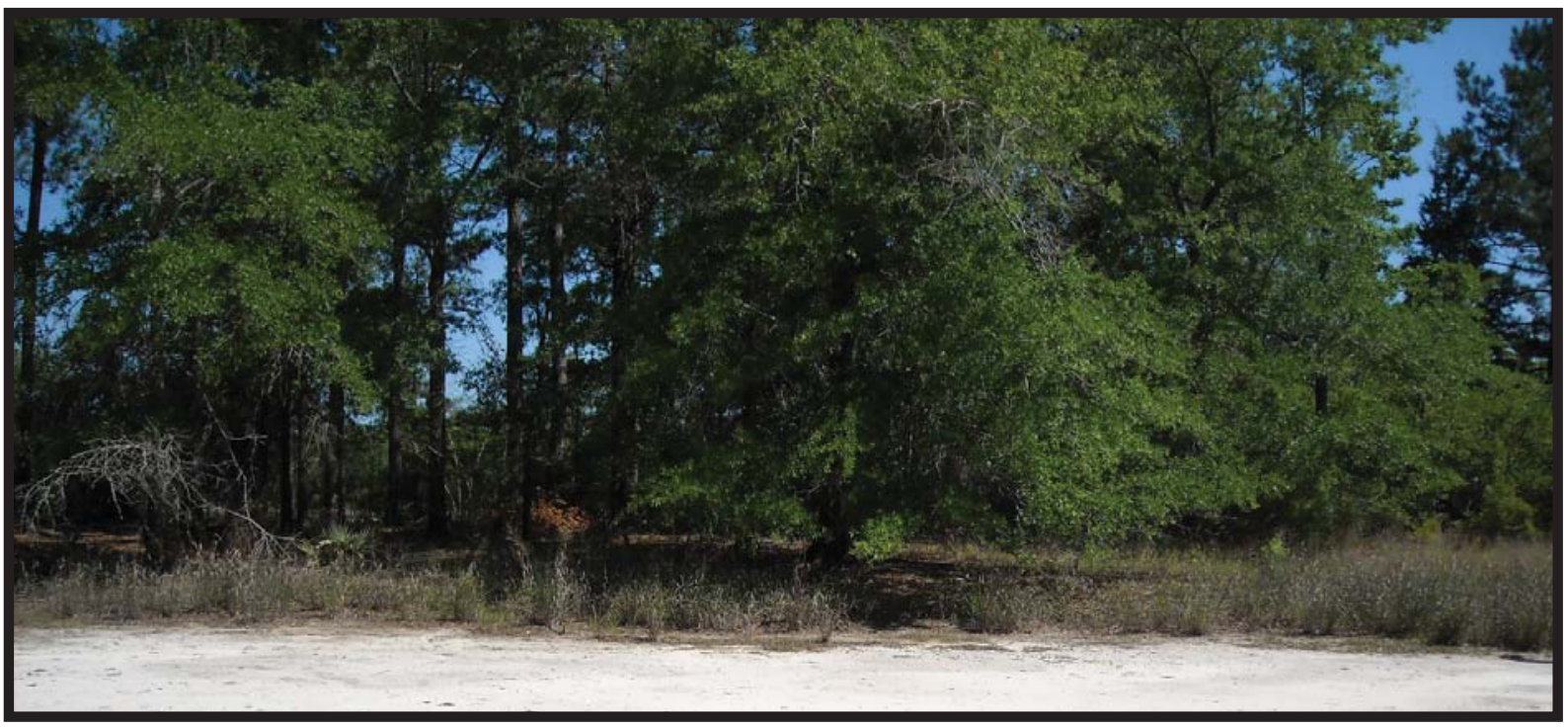

Figure 3. Widdish Island on the Upper Lick Salt Flat at Drake's Salt Works. 


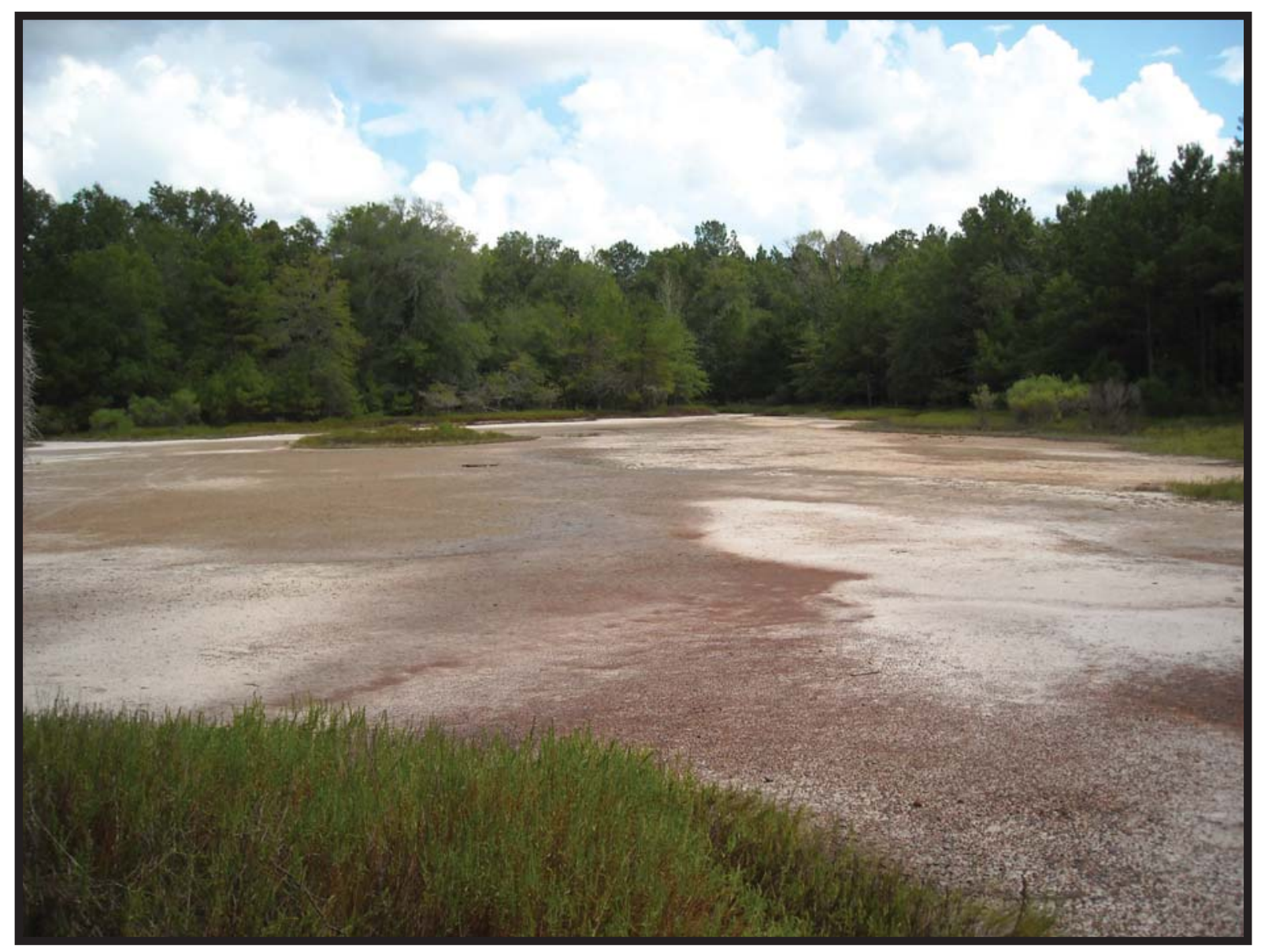

Figure 4. The Little Lick Salt Flat at Drake's Salt Works.

\section{Caddo Salt Making at Drake's Salt Works}

Previous investigations of Caddo salt making at the Hardman saline (3CL418) in southern Arkansas and the Salt Well Slough site (41RR204) in eastern Texas, suggest that the Caddo first began producing salt in noticeable quantities around A.D. 1300/1400 (Early 1993; Kenmotsu 2001; 2005). Curiously, it appears that intensive salt production did not begin in northwestern Louisiana until sometime after A.D. 1500/1600 or slightly later (Eubanks 2014a; Girard 2006:54-69). Perhaps the delayed onset of salt making in this region implies that maize agriculture was not practiced as intensively as it was in other parts of the Caddo homeland since maize contains very little naturally occurring salt, and at least some additional dietary salt may have been physiologically necessary for maize-dependent populations (Brown 2004:41; Driver and Massey 1957; Dumas 2007). While there are many other salt flats in northwestern Louisiana that have not yet been surveyed archaeologically, Potter's Pond at Lake Bistineau and Drake's Salt Works are the only two salines known to have been utilized by the Caddo for salt production (see Figure 1). The material culture at these two salines is remarkably similar, and it would not be surprising if many of the salt production techniques were shared between the salt makers who worked at these sites. Elsewhere in the traditional Caddo homeland, a variety of vessel forms and salt production techniques were employed that differ from those used at Drake's Salt Works. At the Hardman saline, for instance, a combination of large, basin-shaped saltpans and jars were used to evaporate salt, while at the Salt Well Slough site, neck-banded and plain jars were the preferred cooking vessels (Early 1993; Kenmotsu 2005). Despite these various vessel technologies, it seems that the majority of the salt makers throughout the traditional Caddo homeland preferred evaporating their brine directly over a fire rather than placing heating stones into a briny liquid as was common at salines elsewhere 
in the Southeast (e.g., Brown 1980; Bushnell 1907, 1914; Muller 1984). Thus, while many Caddo salt makers may have shared certain vessel and cooking preferences, it is important to remember that these techniques and technologies were not constant through time or space and that the reconstruction presented here is meant to apply only to Drake's Salt Works.

\section{The Salt Makers at Drake's Salt Works}

The two Caddo groups most closely associated with salt making in the area surrounding Drake's Salt Works were the Doustioni and the Natchitoches (Swanton 1911, 1942, 1946; Webb and Gregory 1978:2829). The Doustioni, whose name is often translated as "Salt People," were known to have lived near Drake's Salt Works during the eighteenth century (Webb and Gregory 1978:28; Swanton 1942). Thus, it is possible that much of the salt produced at Drake's Salt Works was done so by this group. After the eighteenth century, however, there is no record of the Doustioni. While they may have disappeared, it is also conceivable that they intermingled or coalesced with the nearby Natchitoches. The Natchitoches were known to have lived in northwestern and west-central Louisiana, but by 1825 only a couple dozen remained in this area (Swanton 1942:21). Like the Doustioni, the Natchitoches were also known historically for their role in the salt trade (Swanton 1911:204, 1942, 1946:738), and thus, it is possible that this latter group was also making salt at Drake's Salt Works.

At the Little Lick, there is a temporary habitation zone approximately $100 \mathrm{~m}$ away from the salt flat on a $6 \mathrm{~m}$-high hill. Although shell-tempered pottery sherds, burned earth, animal bones, and lithics were found, it is clear that this area has been heavily disturbed by American/Confederate salt production given the amount of brick found in association with these artifacts. Beneath the disturbed soil layers, however, there is little to no evidence of long-term American Indian habitation (Eubanks 2014b). Thus, these artifacts may represent the location of a temporary campsite where the Doustioni or Natchitoches lived while they were making salt (Eubanks 2013a). There are also two similar locations at the Upper Lick. One is on Widdish Island, and the other is on a natural terrace $80 \mathrm{~m}$ to the west. Both of these locales contained finely engraved pottery, animal bone, stone tools, and lithic flakes, but no evidence of permanent architecture. This suggests that like the Little Lick, some form of domestic activity probably occurred here on a temporary or seasonal basis (Eubanks 2014b).

Based on historic and ethnographic data, it seems that the production of salt at Drake's Salt Works would have been conducted primarily by Caddo women. It is also likely that the same individuals involved in making salt were also responsible for making the salt production equipment, which probably included woven baskets, ceramic bowls, and cloth wrapping. Since women are typically associated with the production of these materials in the ethnographic record (Swanton 1942:158, 1946:549), it is reasonable to assume that they were also responsible for making these items at Drake's Salt Works. Further insight into the issue of gender and salt making is found in a report by John Sibley, the American Indian Agent of the New Orleans Territory, who, in 1807, received news that two Nadaco Caddo women were murdered by Choctaw raiders while they were making salt.

Three Caddos arriv'd special messengers from the Caddo chief to inform me that a party of Chactas consisting of eight persons from the great nation under a leader called Stamelachee had lately been at a camp of Nandacos [Nadaco] at a saline on the River Sabine where the Nandacos live, the men being out hunting and left their women [emphasis added] to make salt and had murdered two of the women and wounded some others, without any provocation and brought the scalps of the women through the Conchetta village on their way to the great Chacta Nation (Sibley 1922:22-23; see also Swanton 1942:82). 
Although this incident occurred along the Sabine River in eastern Texas and not at Drake's Salt Works, the analogy involving female salt makers may be reasonably applied to the case at hand given the spatial, temporal, and cultural proximities between the Caddo of eastern Texas and the Caddo of northwestern Louisiana. It is also known among the Osage and Creeks that salt making and hide tanning were primarily female activities (Foreman 1932:476; Swanton 1928:386). Additionally, there is some archaeological evidence to support the argument that Caddo women were the ones primarily responsible for salt making. At many of the salines in northwestern Louisiana and throughout the Southeast, there is often a lack of hunting and knapping-related materials such as projectile points, lithic debitage, and animal bones in the middens of salt production debris. Rather, these artifacts are often not found at all or are found in nearby habitation zones (Eubanks 2014b). Since these materials are most often associated with traditionally male activities, this lends some additional support to the argument that men did not participate in saltmaking activities. It is important to note, however, that while men were likely not heavily involved in the production of salt, this does not mean that they did not visit the salines or that they were not involved in its transportation or trade.

\section{Filtering Techniques}

At Drake's Salt Works today, and probably throughout its use as a Caddo salt production site, highly potent concentrations of brine rarely, if ever, pooled consistently on the ground surface. However, once successive episodes of weak brine surfaced and evaporated, visible deposits of salt could be seen left behind on the dry ground. Since the salt could not be gathered without also collecting a substantial quantity of sand and clay, it would have been necessary to filter out these soil impurities. The filtering of salty earth was a common practice in the Southeast (Brackenridge 1962:66; Brown 1980; Keslin 1964:20) and throughout the world (Adshead 1992; Connah 1996; Davison 1993; Gouletquer 1974; Lovejoy 1986; MacKinnon and Kepecs 1989; McKillop 2002; Morgan 1974:31-37; Parsons 2001; Sutton and Roberts 1968). This practice also did not escape the attention of the Gentleman of Elvas, a Portuguese officer on the De Soto expedition, who observed this technique in use by the salt makers living in the vicinity of present-day western Arkansas:

The salt is made along by a river, which, when the water goes down, leaves it upon the sand. As they cannot gather the salt without a large mixture of sand, it is thrown together into certain baskets they have for the purpose, made large at the mouth and small at the bottom. These are set in the air on a ridge-pole; and the water being thrown on, [ceramic] vessels are placed under them wherein it may fall; then, being strained and placed on the fire, it is boiled away, leaving salt at the bottom (Elvas in Bourne 1904:136).

Filtering was also common in other regions of the world such as Africa, Asia, and Mesoamerica, and this process often had to be repeated several times before all of the impurities were removed (Andrews 1980; Connah 1996; Davison 1993; Fagan and Yellen 1968; Gouletquer 1974; Lovejoy 1986; MacKinnon and Kepecs 1989; Morgan 1974; Multhauf 1978; Nenquin 1961; Parsons 2001; Sutton and Roberts 1968). While it is unknown if the Caddo at Drake's Salt Works filtered their brine multiple times, Louis Juchereau de St. Denis, the first commandant of 
Natchitoches, reported that, "The salt secured from these Indians [the Natchitoches] was whiter and purer than the salt that came from France" (Castañeda 1936:18; see also Swanton 1942:139). Given the high quality of their salt, it remains a distinct possibility that the Caddo at Drake's Salt Works filtered their brine multiple times. Barring periods of prolonged drought, the salt makers at the Upper and Little licks would not have needed to walk far for filtering water since several creeks run through or adjacent to these salt flats. A handful of bottle and jar fragments have also been recovered from Drake's Salt Works, and it is possible that one or both of these vessel forms were used to transport water from the creeks to the nearby filtering areas.

There is also some archaeological evidence to support the argument that the Caddo used woven baskets and water to filter the salt out of the soil. Underneath a thin layer of sand at the Upper and Little salt licks lies a sizeable deposit of gray clay, but this clay would have been ill-suited for pottery production given its high sand content. In an artificial mound of salt production debris at the Little Lick, however, relatively pure deposits of gray clay can be seen in the mound's soil profile. As pure clay deposits such as these have not been documented elsewhere near these salt licks, it is possible that the Caddo were using filtered clay from the salt flat to make their ceramic vessels. If they were filtering the salt out of the sand using baskets, then relatively pure deposits of clay would have been a byproduct of this process, as the heavier sand grains would have settled to the bottom of the basket leaving the smaller clay particles to accumulate separately on top.

\section{Cooking and Vessel Technology}

There are two techniques that the American Indians of North America used to evaporate crystalline salt from liquid brine: sal solar (sun salt) and sal cocida (cooked salt) (Andrews 1983:108-113). The first of these techniques involves concentrating brine in shallow pools or beds where it is evaporated using heat energy from the sun. The second method, sal cocida, refers to brine that is "cooked" directly over a fire or indirectly through the use of heated stones. Sal solar requires no fuel, but this method is often only practiced in coastal regions where there is an abundant supply of seawater, warm temperatures, a steady breeze, limited tree cover, and a predictable dry season. Salt produced via the sal cocida method is not bound by such limitations, and thus, sal cocida would have been the preferred evaporation method in non-coastal areas. In addition, sal cocida could produce crystalline salt in a matter of minutes or hours whereas sal solar may take days or even weeks (Akridge 2008). In many instances, these two methods could have been used in tandem where liquid brine was cooked until it formed a semi-solid salt slurry and then dried using solar energy. At Drake's Salt Works, it is clear that the Caddo salt makers preferred the sal cocida technique, as is evidenced by the tens of thousands of broken pottery sherds left behind at the Upper and Little salt licks. The overwhelming majority of these sherds belonged to thin-walled, hemispherical bowls. These bowls are tempered with shell and a mix of grog, sand, and organic material. Almost all are plain, though scrape marks, possibly resulting from salt extraction, can occasionally be seen on the interior of some of these sherds. 
Throughout eastern North America, the most common vessel associated with salt making is the thick-walled, basin-shaped saltpan. At several Caddo salt production sites, especially those in southern Arkansas, saltpans were the primary pottery vessel involved in the salt making process (Early 1993). At Drake's Salt Works, and throughout northwestern Louisiana, this does not seem to have been the case, since few, if any saltpan sherds have been recovered from this area. While regional or cultural preferences played some role, the use of salt bowls over saltpans at Drake's Salt Works follows a general late prehistoric-early historic period trend seen throughout the Southeast where salt bowls or jars tend to replace saltpans (Figures 5 and 6) (Brown 1999; Eubanks and Dumas 2012; Dumas 2007:536; Kenmotsu 2005). Although it is not known for certain why the Caddo at Drake's Salt Works preferred using salt bowls, it is possible that this technology developed in response to the high demand for salt following European contact. Compared to their saltpan counterparts, salt bowls took less clay to make and would have required a shorter firing time thus allowing a large number of bowls to be produced relatively quickly. The thin walls of the salt bowls would have also permitted heat energy to be transferred more quickly from the fire to the brine compared to the thick walls of a saltpan (Akridge 2008). However, since the thin walls of the salt bowls are prone to spalling, they could seldom be used more than once before breaking. This would not have been a problem at Drake's Salt Works, since clay for additional vessels would have been readily available in mixed deposits directly beneath the salt flats.

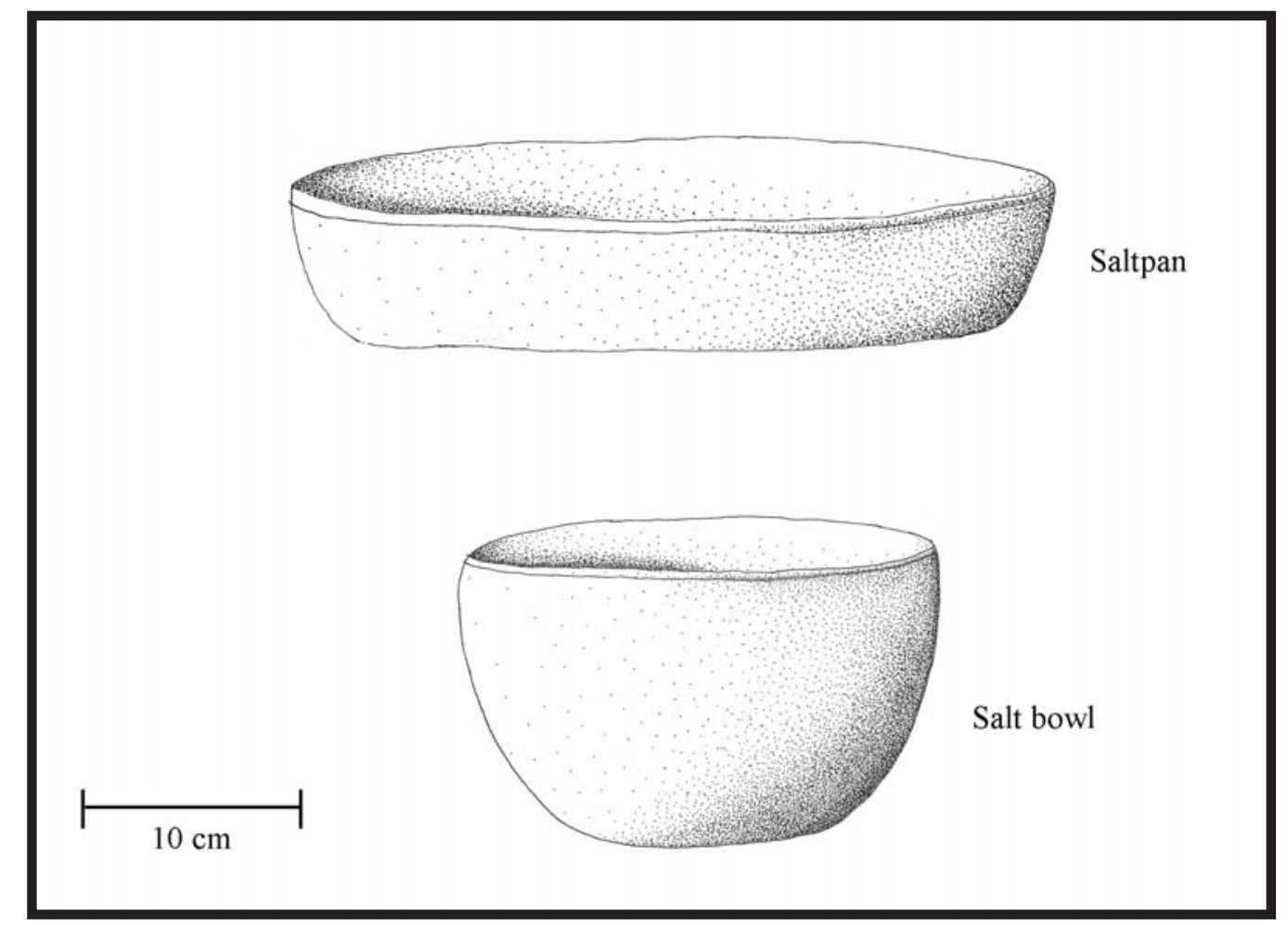

Figure 5. Sketch of a saltpan and a salt bowl. 


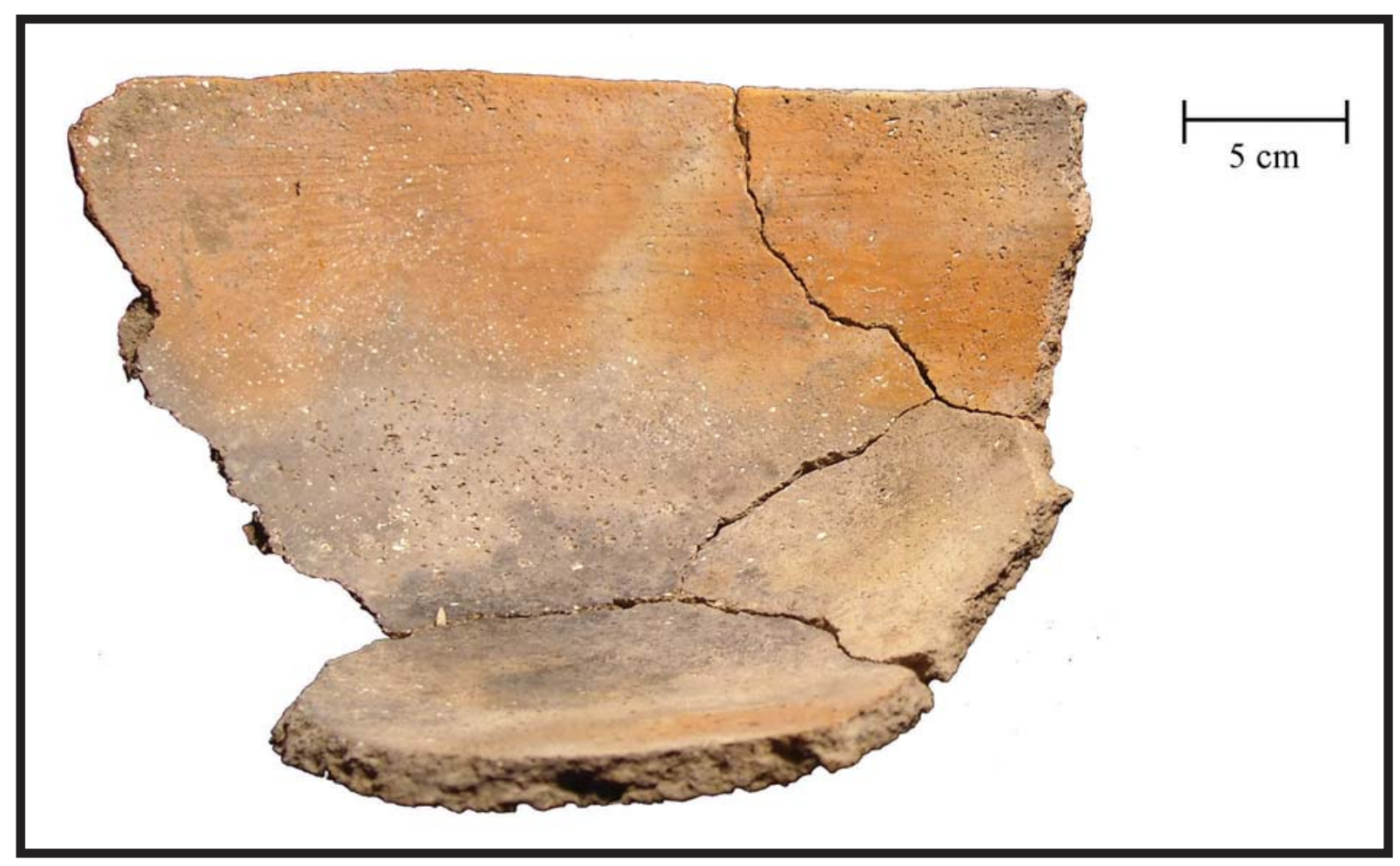

Figure 6. Salt Bowl from the Little Lick at Drake's Salt Works.

There is a precedent elsewhere in the world for brine evaporation vessels being made and fired off-site in order to conserve wood fuel near the saline (e.g., Brown 2010, 2013), but this does not seem to have been the case at Drake's Salt Works. If fuel scarcity was a problem, then it is likely that the salt producers would have moved from lick to lick consuming the available fuel resources while leaving a series of horizontally stratified deposits. Although fuel would have certainly been a concern of the salt makers, it is unlikely that there was a serious fuel shortage at Drake's Salt Works, since most of the salt licks at this site complex do not contain evidence of Caddo salt production. The French historian Le Page Antoine Simon du Pratz (1758:307-308) also provides some insight into this issue:

This [saline] water passes without doubt through some salt mines. It has the salt taste without having the bitterness of the water of the sea. The natives come from quite long distances to this place to hunt during the winter and to make salt here. Before the French sold them kettles they made earthen pots on the spot [emphasis added] for this operation. When they had enough of a load they return to their own country loaded with salt and dry meats (Swanton 1911:78).

Additional support for on-site pottery production can be seen in the salt production debris middens where mussel shells, which would have been used to temper the salt bowls, were found in association with deposits of gray potting clay. 
Once enough potting clay had been collected, the salt makers may have used a combination of coiling and molding to make their salt bowls. Most of the salt bowls at Drake's Salt Works have flat bases, but it is also not uncommon for some bowls to have slightly rounded bases. The bases of the bowls appear to have been made by wrapping a clay coil around itself in a spiral pattern. Once this part of the vessel was made, standard-sized molds may have been used to help shape the rest of the vessel. The average rim diameter of these molds would have been about $20 \mathrm{~cm}$ with roughly 95\% of the rim sherd diameters falling between 16 and $24 \mathrm{~cm}$ (Eubanks 2013b:21). The absence of any visible exterior vessel treatment, such as fabric or cane impressions, suggests that these vessels were molded using a material that did not leave a noticeable impression, such as wood, another pottery bowl, or hardened clay. At present, it seems more likely that wood or another salt bowl was used since no hardened clay pits or domes have been found. It is still possible that fabrics or baskets could have been used as molds, but if this was the case, then the vessel exteriors or interiors were subsequently altered in a way that smoothed over these impressions. In addition to their standardized rim diameters, the rim thickness of these vessels was fairly consistent ranging between 4 and $7 \mathrm{~mm}$. Such low degrees of variability may be reflective of a standardized salt production process geared at producing large amounts of salt as quickly and efficiently as possible.

The preferred vessel technology for evaporating brine began to change sometime after sustained European contact in the early eighteenth century as the Caddo began to incorporate metal kettles obtained from the French. According to Le Page du Pratz, who is believed to have visited Drake's Salt Works, the French would sell brass kettles to the Caddo for the purposes of salt making (Le Page du Pratz 1758:307-308; see also Swanton 1911:78). While no evidence of these kettles have been found at these salt works to date, this is not surprising since most, if not all, of these containers would have been recycled or repurposed in some manner (e.g., Brain 1979:164; Quimby 1968:72; Woolworth 1975:91).

Very few examples of fire-altered stone have been recovered from Drake's Salt Works. This, along with the abundance of charred wood remains suggests that the brine was heated by placing the salt production vessels directly over a fire. Additional support for direct heating over indirect heating is also found in the above account from the Gentleman of Elvas who observed the Caddo evaporating liquid brine directly over a fire (Bourne 1904:136; Swanton 1946:301). The heating process appears to have been carried out in open-air hearths on or around elevated areas adjacent to the salt flat (Figure 7). In addition to allowing the salt makers to remain at the site during brief periods of rain, these elevated areas would have also been a good source of wood for shade and fuel since trees are rarely able to grow on the salt flat itself due to the high salt content of the soil. At the Upper Lick, the majority of the salt production debris is concentrated on Widdish Island, a 2 m-high rise in the salt flat (see Figure 3), while at the Little Lick, a 1 m-high deliberately constructed rise on the edge of the salt flat composed primarily of salt production debris was utilized (Figure 8). 


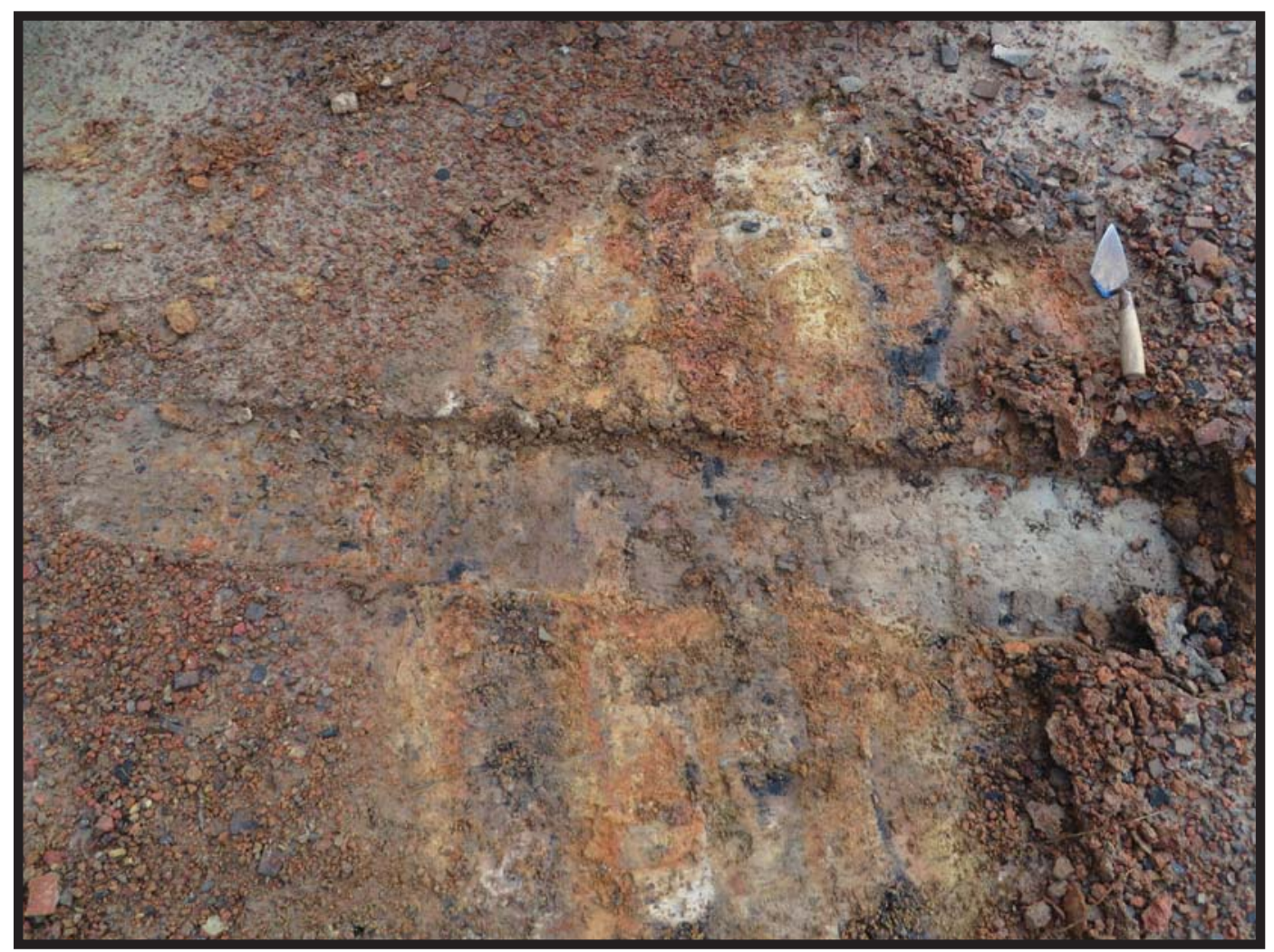

Figure 7. A bisected open air hearth on the Little Lick Salt Flat.

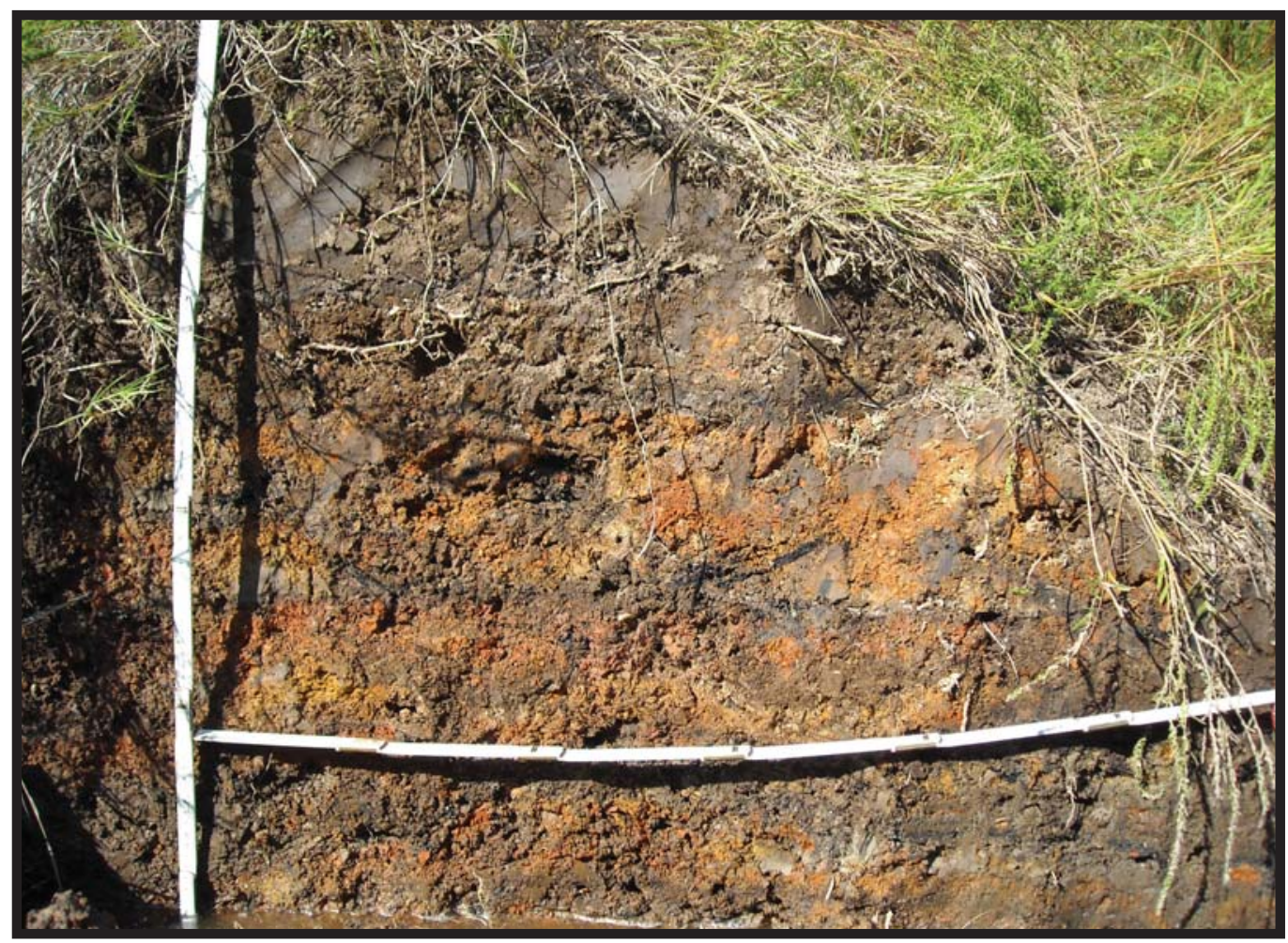

Figure 8. Profile cut from the mound of salt production debris at the Little Lick Salt Flat. 


\section{Transport and Trade}

After the salt was evaporated out of liquid brine, the producers would have needed to dry the salt cakes before they could be stored or transported. There are several ways that this could have been achieved. First, the salt may have been left in the salt bowl over a fire until it was completely dry. This method probably would have resulted in dried salt solidifying on the interior walls of the vessels, meaning that the vessels would have to be scraped out or broken open intentionally to remove the salt. The high vessel breakage rate and the occasional scrape marks found on the interiors of salt bowls lend some support to this hypothesis. In addition, given the high spalling rate associated with evaporating salt water, it may have been the case that each bowl could only be used once anyway (Kenmotsu 2005:32).

It is also possible that the sal solar technique was used for this final stage of production. Sal solar would have been more fuel efficient, but there is little archaeological or historical evidence suggesting that this technique was used. If it was used, then the salt makers may have simply left the salt bowls with their partially-evaporated salt slurries out in the sun. They could have also laid the semi-solid salt cakes out to dry on pieces of fabric. This latter method would presumably have been advantageous in that once the salt cakes were dry they could easily be wrapped in the same fabric and prepared for transport or storage.

In the late 1680s, Henri Joutel, a survivor of René-Robert Cavelier Sieur de La Salle's failed attempt to establish a colony at the mouth of the Mississippi River, reported that he encountered two Caddo traders on their way to the Quapaw to sell bows, arrows, and salt. He described the salt cakes as "little loaves...weighing about two to three pounds apiece" (Swanton 1942:138-139). These traders claimed to have gotten the salt from the Tunica, which raises the possibility that non-Caddo groups were involved in salt production in northwestern Louisiana or at Drake's Salt Works. However, it could also be the case that the Tunica obtained this salt from one Caddo group and then traded it to a different group of Caddo traders. Regardless of if the Tunica made the salt themselves or traded for it, if Joutel's observation characterized a typical unit of trade for salt, then the salt makers at Drake's Salt Works may have also been making similarly sized salt cakes. Given the limited range of variability exhibited by the salt bowls, it would have been relatively easy for the Drake's Salt Works salt makers to produce a standard, two-three pound salt cake.

In addition to Joutel's observation, Jean-Baptiste Le Moyne, Sieur de Bienville reported in March of 1700 that he happened upon a small group of Ouachita with "several canoes loaded with salt" to sell to the Taensa and that several days later he also encountered "six Nadchitos on their way to the Coroas to sell salt" (McWilliams 1981:146-149). In June of 1716, Bienville also reported seeing eight Natchitoches traders in a pirogue filled with salt. From these examples, it may be assumed that small groups of traders, ranging in size from two to less than a dozen people, were responsible for selling and trading salt. Many of the individuals selling salt were not involved directly in the salt making process, as is evidenced by Joutel's account of the Caddo traders who 
were selling salt acquired from the Tunica. However, it is possible that some salt traders may have also been salt makers or related to the individuals involved in this process. Although difficult to demonstrate given the information at hand, if the Caddo women were in charge of making salt, then responsibility for transporting and trading the salt cakes may have fallen to their male relatives.

In the early eighteenth century, the French explorer Jean Baptiste Bénard de la Harpe observed that the Caddo were capable of producing and trading relatively large quantities of salt. In 1718, la Harpe was commissioned to establish a trading post among the Kadohadacho near presentday Texarkana, Texas. Later, in May of 1719, he sent two of his soldiers out to purchase salt from a saline located three days' journey away by stream. These soldiers returned to la Harpe's trading post with 200 lbs of salt (Margry 1875-1886:272; Swanton 1942:139-140). The Spanish missionary Fray Juan Agustín Morfi also provides some insight into how much salt a saline was capable of producing. In September of 1721 he reported:

The Indians informed him [Marquis of San Miguel de Aguayo, the Spanish governor of Coahuila and Texas] of a saline located fifteen leagues from the fort [Los Adaes]. A lieutenant was sent with twenty men to reconnoiter it, who brought back twenty-five mules laden with salt ore, of such high grade that it yielded fifty per cent; that is, one arroba of salt ore yields half an arroba of excellent salt (Morfi 1935:217-219; see also Swanton 1942:64).

From this account, an estimate of the amount of salt that the Caddo traded to the Spanish can be made. Conservatively, if each mule only carried two loaves of salt and if each loaf weighed two to three pounds, as Joutel suggested, then at least 100-150 lbs of salt were traded to the Spanish at the Los Adaes presido.

The quantities of salt described in the above accounts suggest that the Caddo salt makers may have stored loaves of salt at or near a saline. In order to keep an eye on their salt stores, the salt makers would have had to remain at the saline until their reserves were emptied. Alternately, they could have carried the salt with them whenever they left the saline for extended periods of time, since it was apparently not uncommon for salines to be raided (Sibley 1922:22-23).

After the establishment of Natchitoches in 1714, the Caddo at Drake's Salt Works would have been a short journey from a major French trading post (see Figure 1). It is also no coincidence that Natchitoches, Louisiana's oldest permanent settlement, is located so close to Drake's Salt Works. This fact did not escape St. Denis, who noted it was the French desire for salt that helped to bring these two groups together (Castañeda 1936:18). Jacques de la Chaise, a French royal commissioner, also provides some insight into the general outlook on salt in Louisiana when he reported that, "Salt is extremely rare here. Private persons sell it for as much as sixty sous [approximately \$1.25 in current U.S. dollars] a pound” (Rowland and Sanders 1929:314).

The arrival of a market in Natchitoches would have almost certainly resulted in greater profits for the Caddo salt makers, given the proximity of Drake's Salt Works to this trading post. 
Traveling by canoe, it would have taken less than an afternoon for the Caddo salt traders to reach the confluence of Saline Bayou with the Red River, where they could then trade their salt to the French. Given that glass trade beads, kaolin pipe stems, gunflints, European pottery, and salt kettles have either been found at the salines or were recorded by European explorers, it is reasonable to infer that these items may have been traded to the salt makers in exchange for salt (Le Page du Pratz 1758:307-308; Eubanks 2013a; Gregory 1973:257; Swanton 1946:301-302).

\section{Antebellum and Civil War Use of Drake's Salt Works}

The Caddo continued to make salt at Drake's Salt Works until sometime between the late eighteenth century and the early nineteenth century (Phillips 1962; Sibley 1805:56; Veatch 1902:55-56). In April of 1805, the American Indian Agent John Sibley reported to General Dearborn, the Secretary of War, that "two old men" were making six bushels of salt each day from a dozen salt wells at Drake's Salt Works (Sibley 1805:49-65; Veatch 1902:55-56). By 1816, the saline had acquired the named "Postlewait's Salt Works" after its current owner (Phillips 1962:33). In the early 1840 s, Reuben Drake, who by this time owned much of the site, excavated numerous wood-lined salt wells. One of these wells was drilled to a depth of $1011 \mathrm{ft}$. and was capable of producing 18 to 20 gallons of brine a minute (Hilgard 1883). The brine from wells such as this was often transported away from the salt flat or pumped into a trench where it was transported to a boiling furnace. Some furnaces contained rectangular or circular salt kettles, while others housed a cylindrical metal boiler that was split in half and mounded on each side with brick and/or ferruginous sandstone. The intensity of salt production increased dramatically at Drake's Salt Works during the Civil War, especially after the Union Blockade of New Orleans in 1862. Once the port of New Orleans was reopened, however, intensive salt production ceased as this commodity could no longer be produced at a cost that would permit it to be competitive on a regional or national market.

\section{An Imagined Day in the Life of the Caddo Salt Makers at Drake's Salt Works}

It was early spring, the height of the salt making season. Several days ago, the French commandant at the Natchitoches trading post had commissioned a group of six Doustioni women to make $100 \mathrm{lbs}$. of salt in exchange for money and a myriad of trade goods including beaded necklaces, smoking pipes, and a brass kettle. Following this arrangement, the Doustioni salt makers had been hard at work, and today, they needed only to make a dozen salt cakes before the arrival of the French.

Upon leaving their camp in the early hours of the morning, the women gathered their woven baskets and loaded them up with jars, bottles, pieces of fabric, and stacks of pottery bowls. They did not have to walk far as their camp was located little more than a stone's throw from the salt flat. Once they reached their workplace and emptied their baskets, the women went out to the center of the flat and began to scrape up small piles of salty soil. After twelve piles were made, they were scooped into the woven baskets and carried to the forest's edge just beside the salt flat. Three of the women tied these baskets to wooden poles and tree limbs and dug small holes in the 
ground beneath the suspended baskets. The bases of the ceramic bowls were then placed into these depressions so that they would not tip over. Meanwhile, the other women collected water from the creek using jars and bottles. These women then poured this water into the woven baskets and began filtering the salt out of the soil. In order to ensure that their salt was free of impurities, they filtered the liquid brine through the baskets several times.

Next, most of the women carried the ceramic bowls away from the wet filtering area to a dry, open-air hearth on a mound near the edge of the salt flat. With wood that they had gathered the previous day, they started a fire in the hearth and began to heat the brine. Back at the filtering area, the remaining women emptied the soil from the baskets. The filtering process had not only removed salt from the soil, it had also separated and arranged soil particles by size and weight. The larger and heavier sand grains settled to the bottom of the baskets while the smaller clay granules were left on top. The left over sand was taken to an elevated, earthen platform on the edge of the salt flat to shore up an area that had eroded during last year's flood. The clay, meanwhile, was set aside to make more ceramic bowls. Although the bowls were not aesthetically pleasing, they were functional and easy to coil, especially when using an already-fired ceramic bowl for a mold. The resulting standardized bowls had the effect of producing a standardized salt cake, which helped the women judge the weight and value of their salt.

After the liquid brine evaporated over the fire, the salt cakes, weighing about two to three pounds each, were removed from their ceramic containers. Some of the salt had crusted onto the vessels walls and to get it out the vessels had to be scraped or broken open. The women did not mind breaking these vessels open to remove the salt, especially the ones that had started to spall or break apart during the evaporation process. Most of the salt cakes were completely dry, but a few were not. The latter were laid out on pieces of fabric in the salt flat so that they could finish drying. When the drying was finished, the women tied up each salt cake using a cord and piece of cloth.

As the workday neared its end, the French soldiers that had been dispatched from the nearby Natchitoches trading post reached the salt lick. Although the salt was a rare and important commodity, valued at sixty sous a pound, the Caddo salt traders agreed to accept slightly less, in exchange for some additional trade goods. After the terms of the exchange were agreed upon, the French soldiers loaded the salt cakes into their canoes and were home before nightfall. 


\section{Acknowledgements}

Funds to support the research presented here were provided by the National Science Foundation, the Avery Island Inc./McIlhenny Company, the University of Alabama's Anthropology Department, and the University of Alabama's College of Arts and Sciences. The United States Forest Service, especially Velicia Bergstrom, Daniel Cain, Gregory Cohrs, and Barbara Poole, should also be recognized for their roles in the recent archaeological research at Drake's Salt Works. I would also like to thank Reed Franklin and Jim Williams for allowing the University of Alabama and the United States Forest Service to excavate on their property.

${ }^{1}$ In the fall of 2011 and 2012, the United States Forest Service sponsored two archaeological projects that allowed dozens of volunteers from across the country to conduct excavations at Drake's Salt Works. These projects, along with the excavations conducted by the University of Alabama in the fall of 2013 and the spring of 2014, are responsible for most of the data recovered from the Upper and Little salt licks. 
Adshead, Samuel A.

\section{References Cited}

1992 Primitivity. In Salt and Civilization, by Samuel A. Adshead, pp. 3-26. Macmillan Academic and Professional Ltd., Houndmills and London.

Akridge, D. Glen

2008 Methods for Calculating Brine Evaporation Rates During Salt Production. Journal of Archaeological Science 35(6):1435-1462.

Andrews, Anthony P.

1980 The Salt Trade of the Ancient Maya. Archaeology 33(4): 24-33.

1983 The Evolution of Salt-making Technology. In Maya Salt Production and Trade, by Anthony P. Andrews, pp. 108-113. The University of Arizona Press, Tucson.

Bourne, Edward G. (editor)

1904 Narratives of the Career of Hernando de Soto, 2 Vols. A. S. Barnes \& Co., New York.

Brackenridge, Henry M.

1962 Views of Louisiana, Together with a Journal of a Voyage up the Missouri River, in 1811. Quadrangle Books, Inc. Chicago. Originally published 1814.

Brain, Jeffrey P.

1977 On the Tunica Trail. Louisiana Archaeological Survey and Antiquities Commission Anthropological Study No.1. Baton Rouge.

1979 Tunica Treasure. Papers of the Peabody Museum of Archaeology and Ethnology Vol. 71. Harvard University, Cambridge.

1988 Tunica Archaeology. Papers of the Peabody Museum of Archaeology and Ethnology Vol. 78. Harvard University, Cambridge.

1990 The Tunica-Biloxi. Chelsea House Publishers, New York and Philadelphia.

Brown, Ian W.

1980 Salt and the Eastern North American Indian: An Archaeological Study. Lower Mississippi Valley Survey Bulletin No. 6. Peabody Museum, Harvard University.

1999 Salt Manufacture and Trade from the Perspective of Avery Island, Louisiana. Midcontinental Journal of Archaeology 24(2):113-151.

2004 Why Study Salt? Journal of Alabama Archaeology 50(1):36-49.

2010 The Archaeology of Salt Springs in the Eastern Woodlands of the United States. In Salt Archaeology in China, Vol. 2: Global Comparative Studies, edited by Shuicheng Li and Lothar von Falkenhausen, pp. 375-409. Kexue chubanshe (Science Press), Bejing.

2013 The Red Hills of Essex: Studying Salt in England. Borgo Publishing, Tuscaloosa, Alabama.

Bushnell, David I., Jr.

1907 Primitive Salt-making in the Mississippi Valley, I. Man 13:1-5.

1914 Archaeological Investigations in Ste. Genevieve County, Missouri. Proceedings of the United States National Museum 46:641-668. 
Castañeda, Carlos E.

\section{References Cited (cont.)}

1936 Catholic Heritage in Texas, 1519-1936. Vol. 1, The Mission Era: The Finding of Texas, 15191693. Von Boeckmann-Jones Company, Austin.

Connah, Graham

1996 Kibiro: The Salt of Bunyoro, Past and Present. Memoirs of the British Institute in Eastern Africa No. 13. London.

Dauphinée, James A.

1960 Sodium Chloride in Physiology, Nutrition, and Medicine. In Sodium Chloride: The Production and Properties of Salt and Brine, edited by Dale W. Kaufmann, pp. 382-453. American Chemical Society Monograph Series. Reinhold Publishing Corporation, New York, and Chapman and Hall, Ltd., London.

Davison, Spana

1993 Saltmaking in Early Malawi. Azania 28:7-46.

Driver, Harold E, and William Massey.

1957 Comparative Studies of North American Indians. Transactions of the American Philosophical Society 47:165-456.

Dumas, Ashley A.

2007 The Role of Salt in the Late Woodland to Early Mississippian Transition in Southwest Alabama. Ph.D. Dissertation, Department of Anthropology, The University of Alabama, Tuscaloosa.

Early, Ann M. (editor)

1993 Caddoan Saltmakers in the Ouachita Valley: The Hardman Site. Research Series No. 43, Arkansas Archeological Survey, Fayetteville.

Eubanks, Paul N.

2013a Fall 2013 Summary of the Red River Saline Project's Test Excavations at Drake's Salt Works. Report submitted to the Gulf Coast Survey, Alabama Museum of Natural History, Tuscaloosa. 2013b Report of the 2012 Passport in Time Project at Drake's Salt Works (16Wn30 \& 16Na11/17). Report submitted to the United States Forest Service, Kisatchie National Forest Southern Research Station, Alexandria, Louisiana.

2014a The Timing and Distribution of Caddo Salt Production in Northwestern Louisiana. Southeastern Archaeology 33(1):108-122.

2014b Spring 2014 Summary of the Red River Saline Project's Excavations at Drake's Salt Works. Report submitted to the Gulf Coast Survey, Alabama Museum of Natural History, Tuscaloosa.

Eubanks, Paul N., and Ashley A. Dumas

2012 A Hypothetical Reconstruction of the Salt Making Process at the Stimpson Site in Southern Alabama. Paper presented at the 2012 winter meeting of the Alabama Archaeological Society, Montgomery. 
Eubanks, Paul N., and Erin C. Smith

\section{References Cited (cont.)}

2012 Report of the 2011 Passport in Time Project at Drake's Salt Works (16Wn30). Report submitted to the United States Forest Service, Kisatchie National Forest Southern Research Station, Alexandria, Louisiana.

Fagan, Brian M., and John E. Yellen

1968 Ancient Salt-working in Southern Tanzania. Azania 3:1-43.

Foreman, Grant

1932 Salt Works in Early Oklahoma. Chronicles of Oklahoma 10(4):474-500.

Girard, Jeffrey S.

2006 Sites at Lake Bistineau. Regional Archaeology Program Management Unit 1, Seventh Annual Report, Northwestern State University, Natchitoches, Louisiana.

Gouletquer, Pierre. L.

1974 The Development of Salt Making in Prehistoric Europe. Essex Journal 8(1):2-14.

Gregory, Hiram F.

1973 Eighteenth Century Caddoan Archaeology: A Study in Models and Interpretation. Ph.D. Dissertation, Department of Anthropology, Southern Methodist University, Dallas.

Hilgard, Eugene W.

1883 The Salines of Louisiana. In Mineral Resources U.S. for 1882, pp. 554-565.

Hofman, Jack L.

1984 The Plains Villagers: The Custer Phase. In Prehistory of Oklahoma, edited by Robert E. Bell, pp. 287-305. Academic Press, Orlando.

Hunter, Helen V.

1940 The Ethnography of Salt in Aboriginal North America. M.A. Thesis, Department of Anthropology, University of Pennsylvania, Philadelphia.

Kenmotsu, Nancy A.

2001 Salt Well Slough. Bulletin of the Texas Archeological Society 72: 213-222.

2005 Investigations at the Salt Well Slough, 41RR204, A Salt-Making Site in Red River County, Texas. Texas Historical Commission, Archaeological Reports Series No. 4. Austin.

Keslin, Richard 0.

1964 Archaeological Implications on the Role of Salt as an Element of Cultural Diffusion. The Missouri Archaeologist 26:1-181. Columbia.

Kidder, Tristram R.

1998 Rethinking Caddoan-Lower Mississippi Valley Interaction. In The Native History of the Caddo: Their Place in Southeastern Archaeology and Ethnohistory, edited by Timothy K. Perttula and James E. Bruseth, pp. 129-143. Studies in Archeology 30. Texas Archaeological Research Laboratory, University of Texas at Austin. 
Le Page du Pratz, Antoine Simon

\section{References Cited (cont.)}

1758 Histoire de la Louisiane, Contenant la Découverte de ce Vaste Pays; sa Déscription Géographique; un Voyage dans les Terres; l'Histoire Naturelle; les Mours, Coûtumes \& Religion des Naturels, avec leurs Origines. De Bure, Delaguette, \& Lambert, Paris.

Lovejoy, Paul E.

1986 Salt of the Desert Sun: a History of Salt Production and Trade in the Central Sudan. Cambridge University Press, Cambridge.

MacKinnon, J. Jefferson, and Susan M. Kepecs

1989 Prehispanic Saltmaking in Belize: New Evidence. American Antiquity 54(3):1011-1013.

Margry, Pierre

1974 Découvertes et Établissements des Fransais dans l'ouest et le sud de l'Amérqiue Septentrionale (1614-1754). Mémoires et Documents Originaux Recueillis et Publiés par Pierre Margry. Vol 6. AMS Press, New York. Originally published 1875-1886.

McCance, R. A.

1936 Medical Problems in Mineral Metabolism: III - Experimental Human Salt Deficiency. The Lancet, April 11, pp. 823-830, London.

McKillop, Heather

2002 Salt: White Gold of the Ancient Maya. University Press of Florida, Gainesville.

McWilliams, Richebourge C.

1981 Iberville's Gulf Journals. University of Alabama Press, Tuscaloosa.

Meneton, Pierre, Xavier Jeunemaitre, Hugh E. de Wardener, Graham A. McGregor

2005 Links between Dietary Salt Intake, Renal Salt Handling, Blood Pressure, and

Cardiovascular Disease. Physiological Review 85(2):679-715.

Morfi, Juan A.

1935 History of Texas, 1673-1779, Vol 1. Translated by Carlos E. Castañeda. Quivira Society Publications, Albuquerque.

Morgan, David R.

1974 Salt Production in Tanzania: Past and Present. Tanzania Notes and Records 74:31-37. Dar es Salaam.

Morimoto, Taketoshi, Hiroshi Nose, Eizo Sugimoto, Takiko Yawata, and Tadashi Okuno

1993 Role of Sodium Chloride in Rehydration from Thermal Dehydration. In Seventh Symposium on Salt, Vol. 2, edited by Hidetake Kakihana, H. Reginald Hardy, Jr., Takeshi Hoshi, and Ken Toyokura, pp. 389-393. Elsevier Science Publishers B.V., Amsterdam. 
Muller, Jon

\section{References Cited (cont.)}

1984 Mississippian Specialization and Salt. American Antiquity 49(3):489-507.

Multhauf, Robert P.

1978 Neptune's Gift, a History of Common Salt. The John Hopkins University Press, Baltimore and London.

Nenquin, Jacques A. E.

1961 Salt, a Study in Economic Prehistory. Dissertationes Archaeologicae Gandenses 6. Brugge, De Tempel.

Parsons, Jeffrey R.

2001 The Last Saltmakers of Nexquipayac, Mexico: An Archaeological Ethnography. Anthropological Papers No. 92. Museum of Anthropology, University of Michigan, Ann Arbor.

Phillips, Yvonne

1962 Salt Production and Trade in North Louisiana Before 1870. Louisiana Studies 1:28-46.

Quimby, George I.

1966 Indian Culture and European Trade Goods: The Archaeology of the Historic Period in the Western Great Lakes Region. University of Wisconsin Press, Madison, Milwaukee, and London.

Rowland, Dunbar, and Albert S. Sanders

1929 Mississippi Provincial Archives, 1701-1729. Mississippi Department of Archives and History, Jackson.

Sibley, John

1805 An Account of the Red River and the Country Adjacent. American State Papers, Indian Affairs, Vol. 4, pp. 49-65.

1922 A Report from Natchitoches in 1807, edited by Annie H. Abel. Museum of the American Indian, Heye Foundation, Indian Notes and Monographs, Miscellaneous Series 25:5-102.

Sutton, John E. G., and Andrew D. Roberts

1968 Uvinza and Its Salt Industry. Azania 3:45-86.

Swanton, John R.

1911 Indian Tribes of the Lower Mississippi Valley and Adjacent Gulf Coast. Bureau of American Ethnology, Bulletin No. 43, Smithsonian Institution, Washington, D.C.

1928 Aboriginal Culture of the Southeast. Bureau of American Ethnology Forty-second Annual Report for 1924-1925, pp. 673-726. Smithsonian Institution, Washington, D.C.

1929 Myths and Tales of the Southeastern Indians. Bureau of American Ethnology, Bulletin No. 88. Smithsonian Institution, Washington, D.C. 
Swanton, John R. (cont.)

\section{References Cited (cont.)}

1942 Source Material on the History and Ethnology of the Caddo Indians. Bureau of American Ethnology, Bulletin No. 132. Smithsonian Institution, Washington, D.C.

1946 The Indians of the Southeastern United States. Bureau of American Ethnology, Bulletin No. 137. Smithsonian Institution, Washington, D.C.

Veatch, Arthur C.

1902 The Salines of North Louisiana. In A Report on the Geology of Louisiana, by Gilbert D. Harris, Arthur C. Veatch, and Jov. A. A. Pacheco, pp. 47-100. Special Report No. 2. Louisiana State Experiment Station, Geology, and Agriculture, Baton Rouge.

Webb, Clarence H., and Hiram F. Gregory

1978 The Caddo Indians of Louisiana. Louisiana Archaeological Survey and Antiquities Commission Anthropological Study No.2. Baton Rouge.

Wentowski, Gloria

1970 Salt as an Ecological Factor in the Prehistory of the Southeastern United States. M.A. Thesis, Department of Anthropology, University of North Carolina, Chapel Hill.

Whitney, Eleanor, Eva May N. Hamilton, and Sharon R. Rolfes

1990 Understanding Nutrition. 5th Edition. West Publishing Company, St. Paul.

Woolworth, Alan R.

1975 Description of the Artifacts Recovered by the Quetico-Superior Underwater Research

Project. In Voices from the Rapids: An Underwater Search for Fur Trade Artifacts 1960-1973, edited by Robert C. Wheeler, Walter A. Kenyon, Alan R. Woolsworth, and Douglas A. Birk, pp. 55-93. Minnesota Historical Society Press, St. Paul. 